O eixo e a roda, Belo Horizonte, v.25, n.2, p. 151-173, 2016

\title{
Entre a atrocidade e a brutalidade: a estreia de dois contistas em 1922
}

\author{
Between atrocity and brutality: \\ the debut of two short story writers in 1922
}

\begin{abstract}
Marcus Rogério Tavares Sampaio Salgado
Universidade Federal do Rio de Janeiro (UFRJ), Rio de Janeiro / Brasil marcussalgado@gmail.com
\end{abstract}

Resumo: O artigo apresenta um estudo sobre dois livros de contos publicados em 1922: Os condenados, de Gabriel Marques, e Brutalidade, de Afonso Schmidt. Pouco referidas pela historiografia literária, essas obras obtiveram relevante circulação em sua época e representam posições sistêmicas bastante particulares no campo literário brasileiro da década de 1920, apresentando, ainda, convergências estéticas.

Palavras-chave: literatura brasileira; modernismo; neonaturalismo; decadentismo.

Abstract: This article presents a study of two short story collections published in 1922: Os condenados, by Gabriel Marques, and Brutalidade, by Afonso Schmidt. Despite not being often included in mainstream literary historiography, both works achieved notable circulation in their time and represent a very peculiar systemic position in the 1920's Brazilian literary production, not to mention their aesthetic convergences. Keywords: Brazilian literature; modernism; neonaturalism; decadentism.

Recebido em 31 de março de 2016.

Aprovado em 22 de junho de 2016. 
Em 1922, ano em que se realizava a Semana de Arte Moderna, ocorria a estreia como contistas de dois escritores: Gabriel Marques, com seu Os condenados, e Afonso Schmidt, com Brutalidade. Apesar de hoje os dois autores paulistas estarem relegados a um quase completo esquecimento mesmo no plano historiográfico, suas obras representam posições sistêmicas importantes para quem se dispõe a reconstituir as linhas de força atuantes no campo literário brasileiro na terceira década do século XX.

De fato, há pelo menos dois pontos de contato entre $O s$ condenados e Brutalidade. Ambos ostentam fascinação pelo lado obscuro da vida e da psique, seja pela excentricidade, pela depravação, pelo crime ou pela miséria - quando não associados entre si -, o que se explicita desde os títulos das obras, que ressaltam a ideia de violência gráfica ${ }^{1}$ sob os supersignos da brutalidade e da atrocidade (o subtítulo de Os condenados é "contos atrozes"). Além disso, os livros registram com nitidez a oscilação pendular - quando não a síntese - entre o neonaturalismo e o decadentismo epigonal que se verificava na literatura brasileira desde o final da década anterior, fenômeno apontado por Brito Broca no ensaio "Documento de uma época" (cf. BROCA, 1991, p. 368-372) e presente até mesmo no Oswald de Andrade da trilogia Os condenados - cuja escrita e publicação se estendem entre o começo dos anos vinte e o começo dos anos trinta.

\section{A estética da atrocidade}

Gabriel Marques publicou seu primeiro livro de contos, Os condenados, na Coleção Brasília, idealizada por Monteiro Lobato e que muito concorreu para a concretização de incentivos no sentido de "levar a leitura ao alcance de todos e de promover o autor nacional" (PAULILLO, 2002, p. 106). Consta que Monteiro Lobato ter-se-ia interessado em publicar o volume do estreante a fim de ostentar um escritor afrobrasileiro na coleção (CAVALHEIRO, 1955, p. 245). Verdade ou lenda

\footnotetext{
${ }^{1}$ Conceito amplamente difundido na área dos Estudos Culturais para identificar situações na literatura, no cinema e nas artes visuais em que a estetização da violência precede à comunicação de conteúdos morais. Sob essa estratégia representacional, "a violência se sobrepõe à narrativa, transformando-se tanto em seu veículo como em sua determinação" (GRONSTADT, 2008, p. 98, tradução nossa).
} 
dos meios literários paulistanos, o fato é que havia razões tanto literárias como extraliterárias para a publicação de Os condenados. Anteriormente Monteiro Lobato já lançara um autor afro-brasileiro, ninguém menos que Lima Barreto. Por outro lado, há na própria obra de Lobato, em contos como "A vingança da peroba", um certo pendant para o atroz e o escatológico - a confirmar-se, ademais, com a edição de Casa do pavor, de Moacir Deabreu, livro de contos fantásticos com elementos atrozes e brutais, publicado por Monteiro Lobato no mesmo ano que $O s$ condenados.

Hoje praticamente esquecido, Gabriel Marques foi muito ativo na década de 1920, sendo publicadas colaborações suas em diversos periódicos, incluindo o argentino Nuestra Revista, publicado entre 1922 e 1925 como continuação da famosa revista Crisol, na qual se liam textos de Leopoldo Lugones, Ingenieros etc. (cf. LAFLEUR, 2006, p. 163). Segundo a pesquisadora Tânia Regina de Luca (1998, p. 74), a revista argentina, "para marcar a passagem do Centenário da Independência, dedicou todo um número à literatura brasileira, tendo publicado trabalhos de Lobato, Júlio César da Silva, Hugo Carvalho Ramos, Ribeiro Couto, Mário Sette, Lima Barreto, Gabriel Marques e Faria Neves Sobrinho". Sendo a antologia composta quase inteiramente por autores editados por Monteiro Lobato, percebe-se que, à época do lançamento de Os condenados, Gabriel Marques se encontrava no foco da máquina publicitária do editor, com direito a foto na Galeria dos Editados da Revista do Brasil daquele mesmo ano. Ainda em 1922, comparece no número de Natal da revista Frou-frou, que, de par com a qualidade gráfica, notabilizava-se pela circulação entre senhoras e senhoritas de fino trato, pois "em cuchê e com capa em relevo a ouro, custava a espetacular anuidade de 36\$000!” (MARTINS, 2001, p. 231). Em que pese o possível apelo publicitário vislumbrado por Monteiro Lobato ao "usar a imagem do escritor negro para conquistar um grupo específico de leitores" (BIGNOTTO, 2007, p. 245), não se pode deixar de dimensionar o significado da presença de Gabriel Marques, escritor afrodescendente, no circuito mundano da literatura:

O fato de um negro estar entre os escritores retratados pode ser interpretado como uma conquista para os descendentes daqueles homens e mulheres sem nome, carregando livros em cestos, afixando catálogos ou ajudando em tipografias, tão mal mencionados que é preciso procurá-los com lupa 
nos retratos e memórias sobre o início do oitocentos. Conquista que se fez ao longo de boa parte do oitocentos, quando escritores negros começaram a publicar seus trabalhos (BIGNOTTO, 2007, p. 54).

O mapeamento estético das práticas escriturais dos contos que compõem Os condenados aponta, como já dito, para um alinhamento aos neonaturalistas e decadentistas epigonais, ainda em florescimento na literatura brasileira do período. Oscar Mendes (1965), tradutor de Poe, considerava Gabriel Marques um dos escritores brasileiros em cuja obra ressoaria a influência do escritor que definiu o moderno conto em língua inglesa. Ao resenhar Os condenados, Plínio Salgado (1922) detectou ressonâncias de Octave Mirbeau, Zola, Fialho de Almeida e João do Rio, de par com Álvares de Azevedo - também apontado por Agrippino Griecco (1923). Alceu Amoroso Lima nele reconheceu "a tecla sombria do pavor e do mistério que Poe e Hoffmann imortalizaram" (LIMA, 1966, p. 708). De fato, tem lugar na escrita de Marques uma oscilação pendular entre duas matrizes textuais: de um lado, o conto de terror de extração ultrarromântica; de outro, a novela de escândalo neonaturalista - se estava certo Brito Broca (1994, p. 66) ao definir Os condenados como "contos teratológicos de arrepiar os cabelos do leitor".

O conto de abertura, que dá nome ao livro, funciona como síntese do programa estético do ecletismo no qual celebram-se, no mesmo texto, os idioletos naturalista e romântico. O tema do duplo - tão caro ao romantismo, desde $A$ história maravilhosa de Peter Schlemihl, de Chamisso, até "O homem da areia", de Hoffmann, passando por "William Wilson", de Edgar Allan Poe - aparece aqui imiscuído a um caso de xipofagia, com o tratamento clínico característico da obsessão oitocentista por estados mentais fronteiriços. A medicina é vista com certa desconfiança, ora como uma mania ou transtorno de fundo obsessivo, ora como um virtuosismo científico louvável, mas de pouca eficácia no lidar com fenômenos psíquicos. Após o desmembramento dos gêmeos mediante intervenção cirúrgica, irrompe na narrativa outro mito romântico: o da possessão dos vivos pelos mortos. A bem da verdade, mais do que estratégia romântica para lidar esteticamente com a duplicação do eu, trata-se de premissa epistemológica presente em narrativas teogônicas arcaicas: como frisou Freud (1976, p. 252), o duplo tem a ver simultaneamente com "a crença na alma e com o medo 
da morte", que aqui é tratada com o distanciamento clínico característico do enquadramento neonaturalista.

Em última instância, o caso de xipofagia de "Os condenados" é uma variação hiperbólica do tema do duplo. Aqui, o duplo se manifesta não por meio de um sósia, um reflexo ou uma imagem, e sim por um acidente biológico em que se acumulam os motivos da morte da sombra e da "perda da imagem" (RANK, 2014, p. 23), tratados a partir de uma perspectiva representacional sinistra, em que a duplicação transforma-se em "uma cisão tornada independente e visível do Eu (sombra, reflexo)" (RANK, 2014, p. 25). Assim, têm-se aqui o duplo sob uma estratégia mimética de inversão, pela qual se inverte seu aspecto, deixando ele de ser a garantia da imortalidade conferida pela crença na alma e em sua transmigração, para transformar-se em "um estranho anunciador da morte" (FREUD, 1976, p. 294).

O segundo conto, "Os espelhos", retoma o trabalho em torno da duplicação do eu. Uma esposa infiel (Darcy) é mantida em cárcere privado pelo esposo. Sua prisão consiste em um quarto bastante luxuoso, cujas paredes estão revestidas de espelhos. Restringindo-se a seu contato com as imagens projetadas sobre as paredes, passa a identificá-las como sendo guardas que estão ali para controlá-la. Nesse processo, Darcy é atingida pela perda da imagem e, em um ritual de automutilação, corta o seio e apresenta-o às projeções especulares de si mesma, suas guardas. Com a chegada do esposo, Darcy comete um autêntico haraquiri, rasgando o ventre com uma faca, ao que se segue a descrição escatológica do corpo tombando sobre os intestinos.

Como conto, "Os espelhos" sintetiza os pontos frágeis do volume: a narrativa é centrada na cena final, que é de pura violência. Não há, da parte do narrador, qualquer esforço em descrever a dimensão psicológica ou existencial das personagens, e mesmo o processo de enlouquecimento de Darcy é sumariamente traçado, de forma vertiginosa. Em decorrência da escolha por uma estratégia narrativa sem metalepses (portanto, dentro de uma previsível linearidade tanto no plano representacional como no plano da narração), tampouco são apresentadas reflexões mediadoras emitidas pelo narrador ou por qualquer outra voz. A tematização do espelho aqui é bem distinta daquela de "O espelho", de Machado de Assis, por exemplo. Em Marques, a tentativa de penetração naquilo que Bosi (2004, p. 239) chama de “dimensão especular" se faz sob o diapasão de um protocolo de escrita quase clínica, conforme à oscilação pendular 
entre o neonaturalismo e o decadentismo epigonal característica do período. O neonaturalismo retomava as pautas do protocolo artístico do naturalismo do século XIX, conforme definido por Zola em $O$ romance experimental, e que consistia, em linhas gerais, em uma escrita decorrente da observação empírica da vida em seus aspectos mais amplos, incluindo aqueles fisiológicos. Para o decadentismo, era necessário que, a essa atenção arguta dispensada ao sensível, fosse acrescentada a observação da instância psíquica, mesmo em seus estados mais desviantes. Assim, a exacerbação do dado sexual, com as fantasias típicas do romantismo noir e do naturalismo de dicção clínica (projeções especulares, perda da imagem, mutilação, mastectomia, algolagnia), segue tal protocolo.

Em fim de contas, o que está em jogo em "Os espelhos" - como já ocorrera em "Os condenados" - é a possibilidade de o duplo tornar-se uma entidade sinistra e aterrorizante. $\mathrm{O}$ que o marido de Darcy monta é uma verdadeira máquina de tortura psíquica, que lida com elementos explosivos da experiência:

Freud observou que em algumas patologias, como no delírio de ser observado, o ego usa o mecanismo da projeção como defesa. O ego é capaz de projetar para fora conteúdos como algo estranho a si mesmo. Diz que a "estranheza" só poderia ser algo resgatado de um estágio primitivo há muito superado em que o duplo era vivido mais amistosamente. $\mathrm{O}$ duplo converter-se-ia num objeto de terror, como aconteceu nas religiões que sofreram colapso e os deuses transformaram-se em demônios.

Esses fenômenos dão ênfase a algumas formas de perturbações do ego que remetem a estados regressivos, em que o ego não se distinguia nitidamente do mundo externo e de outras pessoas - a indiferenciação inicial dentro/fora, mãe/bebê (PEREIRA, 2005, p. 97).

Outro conto que trata de matéria sexual é "Ecce homo!". Nele, uma jovem tuberculosa tem arrebatamentos místico-sensuais diante de uma imagem de Jesus Cristo no adro da Igreja de São Francisco. Mais uma vez, o autor opta pela hiperbolização das causas para potencializar os efeitos hiperestésicos: misturam-se histeria, delírio místico, toxicomania e pigmalionismo em uma mesma interface narrativa. Mais uma vez, Marques mostra-se tributário das raízes genealógicas de sua escrita. A histeria já fora tematizada pelos naturalistas: Aluísio Azevedo o fizera 
com Magdá, em $O$ homem, e Júlio Ribeiro com Lenita, em $A$ carne. Nesse último, encontra-se até uma cena de pigmalionismo: Lenita observa com gozo erótico os músculos e tendões de uma redução em bronze do "Gladiador Borghese". O terreno das patologias sexuais também era caro aos decadentistas: em Là-bas, por exemplo, a personagem Des Hermies refere-se aos frequentadores de uma missa negra como um "serralho de histero-epilépticos e eterômanos” (HUYSMANS, 2006, p. 277) em plena dissipação de energia sexual. Um dos pontos de vertigem no traçado das linhas serpentinas que compõem Là-bas é a polêmica descrição de uma missa negra ambientada em pleno fin de siècle, antecedida por uma intoxicação coletiva com estramônio e solanáceas (à moda das feiticeiras), atingindo seu momento máximo no misto de oração e imprecação que Huysmans (2006) atribui ao antissacerdote que comanda a cerimônia. "Ecce homo!" é, por sua vez, uma espécie de pastiche do delírio erótico-místico de Teresa d'Ávila desviado pela observação clínica da sexualidade, penetrando-se, assim, no domínio dos rituais de inversão, calcados no prazer erótico da profanação:

O que há - continuou ela - e vou dizer-lhe, é apenas o seguinte: uma paixão que me desnorteou, uma paixão delirante, de todos os sentidos... Paixão que palpita e se contorce e geme dentro do meu ser... Uma paixão que não compreendo... Uma paixão que a pouco e pouco me mata... Eu era feliz com os meus vinte anos. Não sabia ver no homem senão um ser criado à semelhança de Deus. Mas, um dia em que fui à missa das sete, na igreja de São Francisco, e vi lá, em tamanho natural, nu, com os músculos retesados em contrações vitais, o ventre murcho, os braços abertos, e no rosto uma expressão de angústia dolorosa e humaníssima - Jesus, o suave Rabi da Galiléia, senti, aqui dentro, não sei que desejo estranho... Era a primeira vez que eu via Jesus, o Divino Salvador dos Homens, assim humano e assim belo! O escultor talhara-o com mão de mestre... Magro e rijo pareceu-me, entretanto, sentir carne viva e sangue palpitante debaixo daquela brancura marmórea e fria...

Talvez por isso olhei-o com mais atenção, com voluptuosa insistência. E não lhe sei explicar, como disse, o que se passou em mim. O que vi, o que lhe posso afirmar, é que no dia seguinte voltei à igreja muito antes da hora. Ainda 
não havia ninguém. Olhei-o então de perto... Olhei-o, gulosamente, com um estranho desejo de ver bem, de bem sentir o misterioso latejar daquelas veias que eu não via, mas adivinhava... Aqueles músculos salientes, aquele peito másculo, aquele ventre recurvo, liso, chupado... Não, meu amigo, não sei o se passou em mim! Sei que senti como um estalo nos meus cinco sentidos e cai de joelhos, soluçando e orando... Aquela imagem de homem nu, humanizada e dolorosa, pareceu-me prometer coisas com que meu instinto já sonhava... senti-me indignada, imunda, sacrílega, e tive vontade de estraçalhar a minha roupa, de espicaçar a minha carne e de morder, agadanhar, desfazer aquela santa imagem... Saí então atabalhoadamente, com uma voz roufenha a rir nos meus ouvidos e um punhado de brasas a me queimar o ventre... (MARQUES, 1922, p. 43). ${ }^{2}$

A presença de drogas (éter e cocaína) se pauta em consonância com as novelas de escândalo do período - Cocaína, de Álvaro Moreyra; Os mistérios do Rio, de Benjamim Costallat; As enervadas, de Chrysanthème - e também com os romances de Theo-Filho. Antes, ainda, com contos e crônicas de João do Rio como "Visões d'ópio" ou "A aventura de Rozendo Moura". Comum sobretudo na literatura médica do período, a perversão farmacológica encontra-se diretamente ligada à perversão sexual, como explicam em um trabalho de 1924 os médicos Pernambuco Filho e Adauto Botelho, ambos atuantes no Sanatório Botafogo. Sobre o éter assim se manifestam os doutos pesquisadores:

O véu da narcose vai caindo lentamente sobre a vida... Os ruídos do mundo externo, tocam superficialmente aos ouvidos em surdina confusa. As sensações periféricas vãose esbatendo, até desaparecerem. Sobrevém a preguiça dos músculos, verdadeira paresia, com ilusões da sensibilidade muscular - como impressões de reviravoltas no vácuo, de volatilização do eu físico etc.

Podem aparecer alucinações elementares de todos os sentidos, parestesias etc.

${ }^{2}$ É traço estilístico de Gabriel Marques o uso reiterado, para efeito expressivo e sugestivo, de reticências. Parece-nos sintomático que, como se observará nas citações extraídas das obras dos médicos Botelho e Pernambuco Filho, até mesmo o discurso científico da época se valesse de semelhante recurso. 
O erotismo, por vezes intenso, com alucinações genitais, imagens voluptuosas, pode, segundo Baillarger, servir como pretexto para acusações falsas de atentados ao pudor (BOTELHO; PERNAMBUCO FILHO, 1924, p. 59).

O mesmo vale para a cocaína e seus efeitos alternativamente afrodisíacos e anafrodisíacos, em ambos os casos amplificando a sensação ao paroxismo:

Os tóxicos são para as funções sexuais um Jano bifronte, verdadeira "espada de Damocles".

De início a cocaína exalta as funções genitais, cedo, porém, traz frigidez sexual e os doentes a ela se acomodam, preferindo a impotência à abstenção do tóxico. Em certo período, nota-se verdadeiro círculo vicioso: os doentes só têm um clarão fugaz de potência sexual no momento que ingerem o tóxico, por outro lado, quanto mais tóxico ingerem, mais se tornam impotentes (BOTELHO; PERNAMBUCO FILHO, 1924, p. 52).

Gabriel Marques publicou outras obras: a novela A canalha (1923) e os contos enfeixados em Os esquecidos de Deus (1926) e Carne vil (1944). O último é uma reedição das narrativas de Os condenados, com alguns acréscimos, lançada pela editora Guaíra. Mas a obra com que o autor granjearia maior sucesso seria Ruas e tradições de São Paulo, espécie de flânerie arqueológica pelas tradições e lendas urbanas da capital paulista.

Marques obteve alguma resposta crítica em sua época. Em resenha de Os condenados, Plínio Salgado (1922, p. 3) percebe na obra "uma revolta contra a infeliz condição dos vaidosos seres humanos, míseros títeres nas mãos de um destino cego, tangidos pelas fatalidades orgânicas, psicológicas e sociais, mordidos pela matilha dos instintos perversos". Justifica, ainda, o programa estético da atrocidade a partir da questão da verossimilhança, alegando, por fim, que a violência está igualmente presente na crônica policial, cuja matéria reflete, por sua vez, o espírito do tempo (SALGADO, 1922). Plínio Salgado - que naquele momento encontrava-se bastante próximo ao grupo modernista, publicando, inclusive, em Klaxon e tomando parte na Semana de Arte - voltaria a resenhar obra de Gabriel Marques no ano seguinte, pelo Correio Paulistano, tratando, com o mesmo entusiasmo, de $A$ canalha. 
Outro que se debruçou sobre a obra de Marques foi Agrippino Griecco. Em resenha de $A$ canalha, o severo crítico reconhecia, apesar dos excessos românticos e daquilo que chama de "retórica da desgraça", tratar-se de "um atento perscrutador de incógnitas espirituais" (GRIECCO, 1923, p. 1), preferindo, ainda, Os condenados a A canalha.

Os esquecidos de Deus acabaria por ganhar menção honrosa no Prêmio da Academia Brasileira de Letras de 1927 na categoria "contos e novelas". Antecedendo os contos que compõem o volume Carne vil, encontra-se todo um aparato de discursos críticos endossadores da obra de Marques, em que se destacam uma apresentação por Luís da Câmara Cascudo e o parecer da comissão julgadora do concurso literário promovido pela Academia Brasileira de Letras em 1927, assinado por Humberto de Campos, Laudelino Freire e Felix Pacheco, em que se mantém a menção de honra ao escritor paulista, malgrado o protesto do acadêmico Gustavo Barroso, que considerava Os esquecidos de Deus uma obra obscena e imoral, indigna de figurar no certame. Vale lembrar que, pouco antes, em 1924, Romeu d'Avellar e Benjamim Costallat tiveram problemas com a polícia de costumes, que das livrarias apreendeu as edições de Os devassos e Mademoiselle Cinema, consideradas obras ultrajantes à moral e aos costumes.

\section{A liga candente de vida e sonho}

Quando Afonso Schmidt publicou Brutalidade, seu primeiro livro de contos, o escritor nascido em Cubatão (SP) não era propriamente um iniciante. Já publicara plaquetes e livros de poesia, além de atuar em diversos periódicos, incluindo alguns de orientação libertária. Em 1906, publicou Lírios roxos e Miniaturas, coleções de versos, a que sucederam Janelas abertas (1911), Mocidade (1921) e a peça teatral Lusitânia (1916). Sua extensa atividade jornalística esparramou-se tanto em jornais como o Jornal do Commercio de São Paulo, A Tribuna de Santos, o Diário de Santos, a Folha da Noite e O Estado de S. Paulo como em Zig-zag (fundado com Oduvaldo Vianna), A Plebe, A Lanterna e $A$ Voz do Povo.

Nos anos 1940 e 1950, foi muito editado e chegou a ganhar prêmios representativos, como o Prêmio Machado de Assis de 1942, instituído no ano anterior pela Academia Brasileira de Letras, concedido ao conjunto da obra do escritor, que, àquela altura, acumulava experiência 
no conto (Tesouros de Cananeia), na novelística (Os impunes), no romance ( $O$ dragão e as virgens), no teatro (As levianas), na opereta (Kelani - a dama da lua), na ficção científica (Zanzalás), na poesia (Garoa e poesia), na crônica (Os negros) e já ostentava alguns títulos com vendas significativas: A marcha (1941), narrativa histórica sobre a escravatura, e A sombra de Júlio Frank (1936), folhetim que inauguraria uma série de livros do autor baseados em lendas urbanas da cidade de São Paulo nos mais diversos períodos históricos. Ainda em 1942, publica Colônia Cecília - romance de uma experiência anarquista, que seria reeditado, nos anos 1980, pela Brasiliense.

Hoje Afonso Schmidt é pouco referido, salvo por pesquisadores dedicados ao rastreamento das relações entre literatura e anarquismo nas primeiras décadas do século XX (caso de Francisco Foot Hardmann, que dedica ao autor algumas páginas em Nem pai nem patrão) ou aqueles empenhados em mapear o campo literário em São Paulo no momento de instauração da modernidade (como ocorre no substancioso trabalho de Maria Célia Paulillo, Tradição e modernidade: Afonso Schmidt e a literatura paulista). No entanto, Schmidt está listado, justamente com Brutalidade, Os impunes e Tesouro de Cananeia no terceiro volume do Cambridge history of Latin-American literature (cf. ECHEVARRÍA; PUPO-WALKER, 1996, p. 797). Quando a União Brasileira dos Escritores criou o Prêmio Juca Pato, naquela mesma sessão já se cogitaram possíveis agraciados, entre os quais consta o nome de Afonso Schmidt, ombreando com figuras de proa da literatura (Guimarães Rosa), da poesia (Drummond), da crítica de arte (Sergio Milliet), da crítica literária (Álvaro Lins), da diplomacia (San Thiago Dantas) e da economia (Celso Furtado), conforme noticiado na Folha de S. Paulo de 2 de dezembro de 1962. De fato, no ano seguinte Afonso Schmidt conquistaria o Juca Pato, como intelectual do ano.

Brutalidade surpreende pela força dramática de alguns contos e pelas qualidades de fatura no tocante à estruturação narrativa.

O volume se abre com "Curiango". O título, que faz referência a uma ave negra cujo canto sinistro se faz ouvir durante a noite, remete ao protagonista, um malandro encarcerado no presídio. Introduz-se aqui o cenário principal da narrativa: a casa de detenção. É dentro dela que os presos preparam, todos os anos, um balão de festa junina. Curiango e seus asseclas (Mateus, preso sob acusação de assassinato, e Zezinho, ladrão) aproveitam-se da oportunidade para improvisar a fuga da personagem 
no interior do balão. Essa fuga, contudo, não é bem-sucedida e logo transforma-se em uma espécie de reedição macabra do voo de Ícaro.

$\mathrm{O}$ narrador do conto foi juiz no júri popular que condenou Curiango ao cárcere. É importante lembrar que Curiango levava uma vida nômade desde a infância, "na camaradagem ociosa dos mendigos e dos cachorros" (SCHMIDT, [s.d.], p. 108). Quando criança, "invejou a sorte dos bulldogs, cuja profissão indecorosa é guardar a propriedade... dos outros" (SCHMIDT, [s.d.], p. 108), afinal, os cães soem ter uma casa e uma panela de angu para si, o que nem sempre esteve à disposição do pequeno Curiango, ave desamparada tateando nas trevas de uma sociedade cujas relações são deformadas pela injustiça social e pela pressão econômica. Acaba por ingressar na vida circense, onde descobre certa habilidade com o tigre. O proprietário do circo, depois de punir com o chicote o ousado empregado, resolve explorar suas habilidades, colocando-o em substituição ao antigo domador já no espetáculo seguinte. A estreia de Curiango (anunciado fraudulentamente como M. Pott, o que não passou despercebido à plateia) foi desastrosa: depois de um confronto com a plateia, que insistia em dele escarnecer, sob a incitação do domador demitido, Curiango, para vingar-se, soltou o tigre contra o público, provocando, além do pânico, mortes e o desmoronamento do circo. O final da peripécia de Curiango é laconicamente apresentado pelo narrador: "Curiango foi preso, e o tigre acabou abatido a tiros de carabina" (SCHMIDT, [s.d.], p. 110).

Diante de um histórico tão negativo que não exclui nem mesmo a cena de origem de Curiango - pois, segundo o narrador, ele teria nascido de uma "hora de brutalidade" (SCHMIDT, [s.d.], v. 8, p. 108) - o voo da personagem confere não apenas tonalidades trágicas à sua biografia, como ainda revela-se enquanto tentativa derradeira e radical para atingir a liberdade, ainda que a experiência esteja marcada pelo signo da fatalidade. Seu grito, à maneira da ave que lhe dá o apelido, penetra na noite e nela ecoa como única possibilidade de revolta em um mundo pré-programado a partir de equações biográficas determinadas pelas posições socioeconômicas. Se a etimologia da palavra está correta - e ela, destarte, deriva de termo quimbundo que significa "preceder" -, Curiango e seu voo icárico são o grito de revolta que precederia as transformações sociais provocadas em horizonte coletivo. De um lado, destino individual; de outro, destino histórico. 
Em termos de estruturação narrativa, chama atenção a presença no mesmo conto de duas cenas em que a tensão dramática atinge elevado grau, chegando a haver certo efeito cumulativo entre ambas. A primeira é a da estreia de Curiango como domador, e nela não se desdobra toda a potência climática; a segunda é a tentativa de fuga, desembocadura da tensão dramática do conto. $\mathrm{O}$ sequenciamento das duas - à maneira de uma escada - é utilizado de forma rentável pelo autor.

O conto com a estruturação narrativa mais complexa é "A boca sem sorriso". A narrativa se inicia com o narrador, Teodoro, a visitar a residência do aristocrático Enéias. Pela rotunda do salão, os dois observam o "pequeno movimento do escurecer" (SCHMIDT, [s.d.], p. 116) naquela rua pacata, enquanto o criado "coloca entre [...] [eles] a flamante bandeja dos venenos coloridos" (SCHMIDT, [s.d.], p. 115). Subitamente, cruza os olhos de Teodoro "um indivíduo que, com a sua presença aguda, vinha quebrar a harmonia enternecedora da hora" (SCHMIDT, [s.d.], p. 116). O desconhecido - com quem Teodoro reconhece estar preso "por uma história sombria" (SCHMIDT, [s.d.], p. 116) - aproxima-se e cumprimenta Enéias, partindo logo depois.

Segue-se, então, uma segunda narrativa, que remete aos tempos em que Teodoro vivia na "mais absoluta miséria" (SCHMIDT, [s.d.], p. 117), a ponto de dormir nas ruas. Certa feita, ao conseguir obter, mediante artifício fraudulento, o dinheiro para dormir sobre uma cama de hotel de viração, encontra no interior do quarto um homem em estado de delírio que lhe conta, então, uma longa narrativa - a terceira a encaixar-se no enquadramento do conto. O homem que conta essa terceira narrativa é, em um caso perturbador de serendipidade, a figura que surgiu diante da janela do salão de Enéias e o cumprimentou, de nome Ricardo. A perturbadora narrativa apresentada por Ricardo é um delírio deambulatório no qual se misturam ambientes de miséria, alucinações olfativas e sonoras, percepções vertiginosas da paisagem urbana e objetos dotados de vida anímica própria, particularmente um par de sapatos de um suicida (certo Salim) que passa a conduzir os passos sonambúlicos do outro. O motivo do duplo comparece aqui pontualmente, associado, por sua vez, à maldição que pesa sobre os pertences de um suicida:

Contaram-lhe uma vez que a alma dos suicidas, quando o corpo se inteiriça e gela, passa para um móvel ou um objeto que lhe está próximo, e ali fica, por longos anos, testemunha impassível da vida que o extinto deveria levar. 
Era lógico, portanto, que a alma do Salim tivesse passado para os seus sapatos. E, andando célere, para não ouvir os que mofassem do rinchar lamentoso do calçado, o homem sentia-se cada vez mais diferente. Já quase nada restava da sua personalidade. Tornava-se inteiramente Salim. Sentia-se muçulmano. Amava alguém que ainda não tivera ocasião de ver (SCHMIDT, [s.d.], p. 135).

A narrativa macabra e fantástica de Ricardo revela-se, no final, obra de um estado temporário de desajuste mental, pois que nasce do sequenciamento fantasioso de eventos e objetos que marcaram sua percepção ao longo daquele dia, mas que não ostentavam, factualmente, ligações entre si. O que Ricardo chama de "maldito desarranjo da cabeça" (SCHMIDT, [s.d.], p. 152) fez com que fatos banais fossem transfigurados em uma narrativa perturbadora e tingida de tons sobrenaturais. Percepções banais e casuais - frutos do deslocamento aleatório de Ricardo pela cidade - são encaixadas por meio de uma pressão constelacional paranoide.

Além do encadeamento das situações narrativas a partir de contínuos lances de acaso - que culminam com o efeito de serendipidade do final do conto -, merece destaque a própria estrutura em encaixe que propicia tais desdobramentos. Ocorrem, aqui, as chamadas "narrativas encaixadas", nas quais "no centro de uma intriga englobante, uma ou várias personagens passam a narrar uma ou várias histórias que elas escrevem, contam ou imaginam" (REUTER, 2002, p. 85).

A reforçar as convergências possíveis com Os condenados, de Gabriel Marques, e outros textos ecléticos do período, desponta o conto "Ouro", em que o protagonista, o poeta Rosenthal, tem uma experiência acidental com haxixe. Além de mais uma vez o acaso desempenhar função estruturante na narrativa, no conto a experiência com a substância alteradora da percepção é extravasada para o interior da instância de linguagem e, sob efeito do potente confeito de haxixe, o "viajante" traz, de torna-bordo, as imagens como ouro extraído de um experimento com o autoenvenenamento. Atento às transformações na percepção provocadas pelo êxtase químico, o narrador descreve a experiência urbana sob efeito da substância:

Rosenthal sentia-se profundamente feliz. A aragem do entardecer passava por entre os seus cabelos como finas mãos enamoradas, numa longa carícia. Todas as cores do crepúsculo se haviam tornado tão vivas, tão brilhantes, 
tão agradáveis à vista, que ele não pode deixar de parar e exclamar com enlevo:

- Parece que há mulheres diluídas no crepúsculo!

O jardim em construção tomava tal magnificência diante de seus olhos dilatados, que ele parou estarrecido sobre o abismo, maravilhado pelo esplendor de um céu imenso que se estrelava e de uma terra infinita, marchetada de flores e de reflexos. Veio-lhe de súbito uma certeza absoluta de que, se se atirasse por sobre as grades, não se esfacelaria na calçada, mas ficaria flutuando entre a terra e o céu, entre as flores e a s estrelas, como aquela nuvenzinha branca que lá ia, velejando pelo azul remotíssimo...

Mas não se atirou. E, de corpo leve como uma pena e de alma transbordante das mais violentas alegrias, seguiu para o quarto. Ia terminar o conto. Levava ideias inéditas, impressões novas, imagens nunca vistas! (SCHMIDT, [s.d.], p. 167).

"Ouro" é outro conto que funciona sob a estratégia da inversão. Em fim de contas, o haxixe criaria um ouro invisível, sem valor no mercado de capitais. Perecível, diga-se, até mesmo sua existência, condicionada à realidade volátil de uma intoxicação passageira. Toda a solidez do ouro dissolve-se sob a efêmera luz alucinatória do sonho do haxixe.

Há dois textos em Brutalidade que remetem à simpatia devotada por Afonso Schmidt à causa libertária.

O primeiro é "Os felizes", em que o protagonista Valério, "anarquista, distribuía manifestos revolucionários" (SCHMIDT, [s.d.], p. 159) na porta de uma fábrica. Preso pela polícia, na sequência Valério é conduzido, numa viatura, até a carceragem da delegacia. Ressalte-se a passagem em que o narrador descreve a vista da cidade a partir da viatura policial:

O carro chegou numa nuvem de pó, ao grito lancinante das sereias. Um soldado que vinha ao lado do motorista abriu a porta do fundo e empurrou o preso para dentro. O secreta comunicou-lhe qualquer coisa e esgueirou-se. A viatura partiu novamente, atirando-se entre os outros veículos, que estacavam à sua passagem.

Dentro daquela caixa negra, semelhante a uma câmara escura de fotografia, Valério teve uma visão inédita da cidade, das casas, dos homens. A vida urbana, ao anoitecer, vista numa 
carreira doida, pelas frestas da veneziana, tinha aspectos novos e deslumbrantes de um quadro luminoso, retalhado em fitas estreitas, separadas entre si... Ora via cardumes de pés que iam e vinham, ora cabeças decepadas, boiando na noite, em todas as atitudes (SCHMIDT, [s.d.], p. 160).

A superlotação e as condições sanitárias precárias das celas são reforçadas pelo narrador, segundo o qual "o ambiente fazia-se de todo irrespirável” (SCHMIDT, [s.d.], p. 162). O protocolo de escrita hiperestésica tenta emular - na experiência de leitura (portanto, no plano sensível), por meio de descrições pormenorizadas de aspectos degradantes ou francamente repulsivos do cenário ou das personagens - a náusea que acomete os ambientes carcerários. É o caso da descrição da comida ali servido, o "lodo negro" (SCHMIDT, [s.d.], p. 163), como a ela se refere o narrador: "O balde transbordava de feijão negro, sem caldo; dele emergiam duas mandíbulas de boi, como que espetadas no entulho, patenteando, ao alto, uma dentuça bovina, esverdeada, monstruosa" (SCHMIDT, [s.d.], p. 163).

$\mathrm{Na}$ cela que lhe é destinada, Valério trava contato com quatro homens que, embora maltrapilhos, mostravam-se bem-humorados, já que não eram propriamente bandidos, e sim moradores de rua que "quando estavam com fome, faziam-se prender para encher o estômago" (SCHMIDT, [s.d.], p. 163). O caso dos quatro - que "dominavam como príncipes no aniquilamento dos reclusos” (SCHMIDT, [s.d.], p. 163) faz com que o anarquista Valério chegue à amarga conclusão de que a prisão, embora cheia de corpos rejeitados (social e/ou economicamente excluídos) pela sociedade de classes, reproduz os vícios desta última: "Foi nessa hora que o meu amigo Valério surpreendeu o mistério das existências, chegando à conclusão de que não há nada mais semelhante ao mundo do que o calabouço, nada mais parecido aos felizes da vida do que as ratazanas do xadrez" (SCHMIDT, [s.d.], p. 163).

O segundo conto é "Harmonia". Como ocorre com "A boca sem sorriso", é uma peça de difícil classificação. Seu desenvolvimento é um pouco mais amplo que o de um conto, mas não chega a delinear-se como uma novela. Nele, Schmidt trata da vida comunitária, tema que será central em Colônia Cecília (1942), uma de suas obras que obtiveram maior sucesso de público. A diferença é que, aqui, além de termos uma criação totalmente ficcional, a narrativa é resolvida, em termos estilísticos, de forma diferenciada. 
O conto se estrutura a partir de dois movimentos narrativos. No primeiro, a fatura decadentista conduz a uma construção cenográfica focalizada no castelo. Os elementos fundamentais da narrativa frenética do século XVIII (de que o decadentismo é um remake) estão presentes, como veremos adiante.

O castelo "ficava no pendor de uma encosta abrupta" (SCHMIDT, [s.d.], p. 178), sendo, portanto, uma construção quase milenar, espetada, por um prodígio arquitetônico, sobre uma escarpa. Era "um verdadeiro ninho de águias, ocupando todo um planalto, protegido por picos agudos e desfiladeiros escorregadios" (SCHMIDT, [s.d.], p. 179). Ali, o vento uivava como uma matilha de cães: "Pareceu-lhe que maltas de cães danados ganiam no alto dos torreões. Mas não eram cães, era o vento" (SCHMIDT, [s.d.], p. 190).

Tal prodígio arquitetônico, contudo, é um lugar maldito. Primeiramente, por ter sido construído "por um lamentoso exército de escravos famintos" (SCHMIDT, [s.d.], p. 179). Depois, pela própria forma de obtenção da riqueza de que o castelo era a máxima expressão: mediante roubos e pilhagens dos vizinhos. Sua riqueza é resultado do sangue e do sacrifício alheios, uma vez que, segundo a ética do narrador, "cada milhão de moedas é o sacrifício de um milhão de homens" (SCHMIDT, [s.d.], p. 179). Assim, tal riqueza obtida mediante a espoliação, o sofrimento e a degradação do outro açulados ao ponto da desumanização, gerara contra a família "a maldição dos séculos" (SCHMIDT, [s.d.], p. 181). Campônios e rendeiros evitam o contato com o protagonista (Doutor Antélius), sendo sua figura e sua presença experimentadas com grande horror. O narrador alega que Antélius recebera, da família, "um servo caduco, um solar amaldiçoado e uma herança que cheirava a sangue" (SCHMIDT, [s.d.], p. 189).

Sendo o Doutor Antélius herdeiro não apenas de um castelo como também de uma linhagem de "gentis-homens de rapina, adestrados no assalto e no massacre" (SCHMIDT, [s.d.], p. 179), a maldição - inicialmente ligada apenas a um lugar - como que contamina o próprio sangue dos Antélius, determinando a sua transmissão orgânica. Inevitavelmente depara-se com a habitual galeria de retratos de família característica da narrativa frenética: "Percorrendo pensativo, de mãos nas costas, a taciturna galeria onde se empoeiravam os retratos dos avoengos, estremecia ao ver em seus rostos pálidos ou sanguíneos o sorriso mau de celerados triunfadores, que era o apanágio da família" (SCHMIDT, 
[s.d.], p. 180). No castelo, "os mortos riam pelas paredes" (SCHMIDT, [s.d.], p. 182). Segundo o narrador, "Antélius era como um prisioneiro dos mortos. Cercava-o, por toda a parte, menos a espessura das muralhas do que a sombria história de seus antepassados" (SCHMIDT, [s.d.], p. 180). Tudo é tão exacerbadamente sombrio que o narrador constrói imagens de plasticidade obtidas mediante violentos contrastes, como essa: "Sobre a areia branca, deslizava como se fora a sombra das sombras" (SCHMIDT, [s.d.], p. 182).

Como todo herói romântico-decadentista, Antélius luta contra essa maldição dupla. O narrador relata, de antemão, que "por índole, educação e hábitos, muito diferia de seus maiores" (SCHMIDT, [s.d.], p. 179). De fato, ao contrário do baixo materialismo sanguinário de seus ancestrais, o Doutor Antélius tinha como norte "o ignoto de um ideal eternamente incompreendido” (SCHMIDT, [s.d.], p. 178), do qual tratar-se-á quando da abordagem do segundo movimento narrativo do conto.

Tendo sobre si a fatalidade do lugar e do sangue, o Doutor Antélius encontra no amor semelhante fatalidade. A mulher por quem se apaixonara - Lenora, que remete imediatamente à personagem de Edgar Allan Poe -, não resiste à pressão da pequena comunidade contra o "namoro maldito" (SCHMIDT, [s.d.], p. 186) e acaba por cometer um love suicide, suicídio por amor. O ápice do primeiro movimento é obtido com a cena do auto-holocausto de Lenora.

Depois da morte da amada, Antélius passa a viver em regime de clausura: "A ponte levadiça foi erguida para sempre" (SCHMIDT, [s.d.], p. 193). A desilusão amorosa parecia ter atingido o protagonista em sua saúde mental, pois fica-se sabendo que as crianças da aldeia começam a desaparecer, justamente por obra de Antélius. Aqui inicia-se o segundo movimento do conto.

Inicialmente, o leitor é levado a crer, pelas palavras do narrador, que Antélius esteja tomado por uma fúria pedófila e homicida semelhante à de Gilles de Rais, personagem nefasta da história francesa que, depois de lutar bravamente ao lado de Joana d'Arc, transformou-se em um louco em busca de poder e magia, não hesitando diante do estupro e do assassinato em série de crianças. A trajetória hedionda de Gilles de Rais ocupa papel central em Là-bas, um dos textos fundamentais do decadentismo finissecular. Mas é exatamente aí que se é surpreendido com uma viragem na narrativa: na verdade, Antélius isolou-se dos demais moradores da aldeia com o objetivo de constituir uma comunidade alternativa, 
identificada como "Harmonia", para onde levava as crianças sequestradas de seus pais a fim de que elas tomassem parte nesse experimento social libertário. A vida pulsante em Harmonia é descoberta pelo abade e pelo burgo-mestre, emblemas óbvios da Igreja e do Estado:

Acompanhando Antélius, que os guiava naquele mundo novo, inesperado, de uma beleza inconcebível, precisamente onde o padre e a autoridade diziam existir o terror, o caos, o inferno, os dois intrusos boquiabriram-se. Já não acreditavam nos seus próprios olhos.

Viam que esse recanto, tido durante meio século como um antro de pavor pelo populacho do burgo, mal informado pelos seus espertos mentores, era habitado por cerca de mil pessoas, por uma família estranha, que vestia túnicas de linho, alvas e frescas, e que prolongava a despreocupação saudável da infância ao longo da vida, com uma satisfação infinita de existir (SCHMIDT, [s.d.], p. 202).

Vale ressaltar como essa reviravolta na narrativa é obtida mediante um artifício de confusão entre o "universo imaginário evocado pelo autor" e o "universo imaginário construído pelo leitor" (TODOROV, 1978, p. 180). Tal artifício consiste em deslizar, temporariamente, a fronteira entre os dois estados narrativos, de forma a apagar e reforçar, em movimento dúplice, a potencial dualidade existente entre ambos.

Harmonia era marcada por um modo de vida utópico, em que a satisfação de existir era posta em primeiro plano. As relações de trabalho também eram regidas pelo princípio do prazer:

Como o trabalho era livre, escolhido segundo a vocação de cada um, todos estavam alegres e cantavam. Aquela gente não compreendia a vida sem o trabalho. O instinto e a compreensão, a necessidade e o exemplo, diziam-lhe que trabalhasse. Ela produzia sem cessar. Privá-la de produzir seria como proibi-la de amar-o mais terrível dos castigos (SCHMIDT, [s.d.], p. 203).

Tendo sido abolida a propriedade em Harmonia, a segurança pública se instaurara automaticamente, tornando desnecessárias a cobiça, a cupidez e a acumulação: "onde a vida de todos está assegurada por todos, quem se apropria de mais de uma enxada ou de mais do que the seja necessário, só pode ser um doido" (SCHMIDT, [s.d.], p. 204). O 
próprio dinheiro deixa de ter valor em uma sociedade organizada a partir da dádiva e do bem comum: ao receber uma moeda, uma das crianças que vivia em Harmonia "levou-a à boca, revirou entre os dedos e, por fim, achando-a inútil, suja, feia, atirou-a para o lago e fugiu a correr, na sua alegria imperturbável de ave estonteada" (SCHMIDT, [s.d.], p. 207).

Antélius resolvera dividir o interior do castelo em cômodos que abrigavam a população desse estado utópico:

Quando se aproximaram do castelo, viram que somente a torre quadrangular, no seu tope, permanecia desmantelada. O corpo do edifício tinha sido apropriado para habitações. Arcadas, corredores, salas de armas, pátios internos, tudo aquilo que durante séculos servira apenas para os senhores feudais passearem o seu tédio inútil, fora transformado em amplos e arejados compartimentos, onde a luz jorrava em cataratas luminosas. O ar vivificante, impregnado das salubres emanações da terra e das árvores, circulava livremente. E o castelo apavorante, que outrora tinha muito de um túmulo, naquela manhã se apresentava como um grande berço, dentro do qual a humanidade rediviva sorria, sorria e cantava (SCHMIDT, [s.d.], p. 204).

É assim que, nesse "cenário de sonho" (SCHMIDT, [s.d.], p. 204), o velho castelo transforma-se de túmulo em berço.

Obviamente, o projeto utópico de Antélius preocupa imensamente o abade e o burgo-mestre - ou seja: a Igreja e o Estado -, uma vez que eles são descartados nessa nova ordem social proposta, conforme se percebe nesse diálogo entre as autoridades e o aristocrata libertário:

- Quem é que pune o roubo, que dirime as querelas, que recolhe o dízimo?

- Ninguém. Aqui todos trabalham para todos. Tudo que existe pertence à comunidade. Somos como devia ser a humanidade inteira: uma grande família. Tudo se baseia na livre escolha e no mútuo entendimento... (SCHMIDT, [s.d.], p. 205).

E é exatamente sob incitação da Igreja e do Estado que a população - por efeito do álcool fornecido pelo burgo-mestre - ataca o castelo e destrói a comunidade de Harmonia, insensível aos apelos de Antélius de que aquelas crianças eram seus filhos. 
No ano seguinte à publicação de Brutalidade, Afonso Schmidt trouxe à luz $O$ s impunes, que, embora seja a rigor uma novela, o autor considerava um conto. Só voltaria ao gênero com Curiango e Tesouros de Cananeia. O primeiro é uma reedição de Brutalidade, com acréscimos e supressões. O segundo, uma compilação de contos bastante irregulares, publicada em 1941.

A força de sua obra como contista permaneceu, sem dúvida, sintetizada em Brutalidade. Para Sérgio Buarque de Holanda, a estreia no gênero "revela um conteur de raras qualidades e único no gênero em todo o Brasil" (HOLANDA, 1996, p. 161). Alceu Amoroso Lima, que dedicou ao livro um de seus Estudos literários, saudava em Brutalidade a "liga candente de vida e de sonho" (LIMA, 1966, p. 706) que o marca. Segundo o crítico, "o livro, fracionado embora em contos, é o drama da vida inexorável e da sociedade absurda esmagando o homem" (LIMA, 1966, p. 707).

De fato, a coexistência na escrita de Afonso Schmidt de tendências tão diversas - que englobam tanto as ressonâncias do decadentismo finissecular quanto a literatura urbana de corte anarquista, nessa liga candente entre a poesia do sonho e a dura prosa da vida - marca sua trajetória e garante a relevância de sua obra como contista exatamente por registrar esse momento eclético, em que soluções estéticas ambivalentes e audaciosas eram colocadas em pauta pela literatura, refletindo as próprias contradições implicadas no processo de inserção do país na modernidade tanto econômica quanto estética.

\section{Referências}

BIGNOTTO, Cilza Carla. Novas perspectivas sobre as práticas editoriais de Monteiro Lobato (1918-1925). 2007. 421 f. Tese (Doutorado em Literatura Brasileira) - Instituto de Estudos da Linguagem, Universidade Estadual de Campinas, Campinas, 2007.

BOSI, Alfredo. O duplo espelho em um conto de Machado de Assis. Estudos avançados, Instituto de Estudos Avançados da Universidade de São Paulo, v. 28, n. 80, p. 237-246, 2004.

BOTELHO, Abel; PERNAMBUCO FILHO. Vicios sociais elegantes. Rio de Janeiro: Livraria Francisco Alves, 1924. 
BROCA, Brito. Naturalistas, parnasianos e decadistas. Campinas: Editora da Unicamp, 1991.

BROCA, Brito. O repórter impenitente. Campinas: Editora da Unicamp, 1994.

CAVALHEIRO, Edgard. Monteiro Lobato: vida e obra. São Paulo: Cia. Editora Nacional, 1955.

ECHEVARRÍA, Roberto González; PUPO-WALKER, Enrique. The Cambridge history of Latin-American literature. Cambridge: Cambridge University Press, 1996. v. 3: Brazilian literature; Bibliographies.

FREUD, Sigmund. O estranho. In: ___. História de uma neurose infantil e outros trabalhos. Rio de Janeiro: Imago, 1976. p. 138-160. (Obras Psicológicas Completas de Sigmund Freud, 17).

GRIECCO, Agrippino. Vida literária. O Jornal, Rio de Janeiro, ano v, n. 1481, p. 1, 4 nov. 1923.

GRONSTANDT, Asbjorn. Transfigurations: violence, death and masculinity in American cinema. Amsterdam: Amsterdam University Press, 2008.

HOLANDA, Sérgio Buarque de. A nova geração santista. In:

O espírito e a letra: estudos de crítica literária. Organização de Antonio Armoni Prado. São Paulo: Companhia das Letras, 1996. v. 1: 1920-1947, p. 159-162.

HUYSMANS, Joris-Karl. Além. Lisboa: Assírio \& Alvim, 2006.

LAFLEUR, Hector et al. Las revistas literarias argentinas (1893-1967). 2. ed. Buenos Aires: El 8vo, Loco Editores, 2006.

LIMA, Alceu Amoroso. Estudos literários. Rio de Janeiro: Aguilar, 1966. v. I.

LUCA, Tânia Regina de. A revista do Brasil: um diagnóstico para a (n)ação. São Paulo: Editora da Unesp, 1998.

MARQUES, Gabriel. Os condenados (contos atrozes). São Paulo: Monteiro Lobato, 1922.

MARTINS, Ana Luíza. Revistas em revista: imprensa e práticas culturais em tempos de República. São Paulo 1890-1922. São Paulo: Edusp, 2001. 
MENDES, Oscar. Influência de Poe no estrangeiro. In: MENDES, Oscar (Org.). Edgar Allan Poe: ficção completa, poesia \& ensaios. Tradução de Oscar Mendes e Milton Amado. Rio de Janeiro: Aguilar, 1965. p. 53-56.

PAULILlO, Maria Célia R. de Almeida. Tradição e modernidade: Afonso Schmidt e a literatura paulista. São Paulo: Annablume, 2002.

PEREIRA, Denise Zimpek. Fantasma transgeracional: possessão ou retorno do não-recalcado? In: TRACHTENBERG, Ana Rosa et al. Transgeracionalidade: de escravo a herdeiro, um destino entre gerações. São Paulo: Casa do Psicólogo, 2005. p. 93-110.

RANK, Otto. O duplo: um estudo psicanalítico. Porto Alegre: Dublinenses, 2014.

REUTER, Yves. A análise da narrativa: o texto, a ficção e a narração. Tradução de Mario Pontes. Rio de Janeiro: Difel, 2002.

SALGADO, Plínio. Os condenados. Correio Paulistano, São Paulo, p. 3, 10 abr. 1922 .

SCHMIDT, Afonso. Obras de Afonso Schmidt. São Paulo: Brasiliense, [s.d.]. v. 8: Tesouro de Cananeia e Brutalidade.

TODOROV, Tzvetan. Poétique de la prose. Paris: Éditions du Seuil, 1978. 